\title{
PENERAPAN TEKNIK PEMBELAJARAN THINKING ALOUD PAIR PROBLEM SOLVING (TAPPS) UNTUK MENINGKATKAN KEMAMPUAN PEMECAHAN MASALAH MATEMATIS PADA POKOK BAHASAN KUBUS DAN BALOK DI KELAS VIII-5 SMP NEGERI 27 JAKARTA
}

\author{
Lusi Lusiyana Aminah, Wardani Rahayu, Ellis Salsabila \\ Program Studi Pendidikan Matematika, FMIPA UNJ
}

\begin{abstract}
Abstrak
Berdasarkan hasil observasi dan hasil tes pendahuluan kemampuan pemecahan masalah matematis yang dilakukan di kelas VIII-5 SMP Negeri 27 Jakarta, dapat dikatakan bahwa kemampuan pemecahan masalah matematis siswa masih rendah, sehingga kemampuan tersebut perlu ditingkatkan. Penerapan teknik pembelajaran thinking aloud pair problem solving (TAPPS) dapat dijadikan sebagai salah satu alternatif dalam pelaksanaan pembelajaran di kelas. Tujuan dari penelitian ini adalah untuk meningkatkan kemampuan pemecahan masalah matematis siswa kelas VIII-5 SMP Negeri 27 Jakarta melalui penerapan teknik pembelajaran TAPPS.

Penelitian ini merupakan penelitian tindakan kelas (classroom action research) yang dilaksanakan dalam tiga siklus, setiap siklus terdiri dari empat tahapan, yaitu: perencanaan, pelaksanaan, pengamatan, dan refleksi. Pembelajaran di setiap siklus dilaksanakan dengan menerapkan teknik TAPPS. Siswa diberikan tes akhir siklus untuk mengukur kemampuan pemecahan masalah matematis siswa. Penelitian ini berlangsung dari bulan maret hingga april 2016 di kelas VIII-5 SMP Negeri 27 Jakarta tahun ajaran 2015/2016 dengan jumlah siswa di kelas sebanyak 36 orang siswa.

Hasil penelitian menunjukkan bahwa penerapan teknik pembelajaran TAPPS dapat meningkatkan kemampuan pemecahan masalah matematis siswa. Hal tersebut ditunjukkan dengan adanya peningkatan nilai rata-rata tes kemampuan pemecahan masalah matematis yang diberikan setiap akhir siklus. Rata-rata nilai kemampuan pemecahan masalah matematis siswa kelas VIII-5 pada penelitian pendahuluan adalah 39,97, pada siklus I meningkat menjadi 67,71, pada siklus II meningkat menjadi 79,98, dan pada siklus III meningkat menjadi 87,27. Jumlah siswa yang mencapai atau melebihi nilai kriteria ketuntasan minimal (KKM) pada tes akhir siklus juga mengalami peningkatan. Pada penelitian pendahuluan hanya ada satu siswa (2,78\%), pada siklus I meningkat menjadi 13 siswa (36,11\%), pada siklus II meningkat menjadi 25 siswa (69,44\%), dan pada siklus III meningkat menjadi 31 orang $(86,11 \%)$
\end{abstract}

Kata Kunci : Kemampuan Pemecahan Masalah Matematis, Teknik TAPPS

\section{PENDAHULUAN}

A. Latar Belakang

Pendidikan merupakan salah satu aspek terpenting dalam upaya meningkatkan kualitas sumber daya manusia disuatu negara. Melalui pendidikan diharapkan manusia dapat berpikir logis, analitis, dan kreatif sehingga dapat bertahan hidup dan mampu menyelesaikan masalah yang ada sesuai dengan perkembangan zaman dan kemajuan teknologi. Salah satu pelajaran yang dapat mengembangkan cara berpikir adalah matematika, sehingga wajar apabila matematika wajib diajarkan kepada siswa sejak sekolah dasar sampai sekolah menengah atas. Selain itu , matematika dijadikan sebagai salah satu pelajaran yang diujikan saat ujian nasional di tingkat SD, SMP, dan SMA.

Salah satu tujuan dari pembelajaran matematika yaitu agar siswa memiliki kemampuan pemecahan masalah matematis. Setiap penugasan dalam pembelajaran matematika dapat digolongkan menjadi dua yaitu latihan dan masalah (Wardani, 2008). Oleh karena itu, kemampuan pemecahan masalah matematis sangat penting untuk dimiliki oleh siswa, karena tidak dapat dipungkiri dalam kehidupan sehari-hari siswa pasti dihadapi dengan masalahmasalah.

Berdasarkan observasi dan wawancara yang dilakukan di kelas VIII-5 SMP Negeri 27 Jakarta, diperoleh hasil bahwa siswa kesulitan mengerjakan soal berbentuk cerita dan soal non 
rutin hal ini terjadi karena guru cenderung memberikan soal yang prosedural dan kurang memberikan kesempatan kepada siswa untuk mengembangkan kemampuannya.

Selanjutnya, untuk mengetahui kemampuan pemecahan masalah matematis siswa, dilakukan tes prapenelitian kepada 36 siswa kelas VIIII-5 pada tanggal 9 November 2015. Tes tersebut berisi 3 soal pemecahan masalah yang telah divalidasi. Rata-rata perolehan nilai tes prapenelitian siswa yaitu 39,97 dengan nilai tertinggi 75 dan terendah yaitu 11 (dalam hal ini penskoran menggunakan nilai 0-100). Hanya terdapat satu siswa yang telah mencapai kriteria ketuntasan minimal (KKM) yaitu 75. Berdasarkan hasil tersebut dapat dikatakan bahwa kemampuan pemecahan masalah matematis siswa tergolong rendah. Untuk mengukur kemampuan pemecahan masalah matematis siswa pada penelitian ini menggunakan langkahlangkah penyelesaian menurut Polya yaitu memahami masalah, merencanakan penyelesaian, melaksanakan penyelesaian, dan memeriksa kembali hasil dan proses.

Salah satu teknik pembelajaran yang dapat meningkatkan kemampuan pemecahan masalah matematis siswa adalah teknik Thinking Aloud Pair Problem Solving (TAPPS). Teknik TAPPS membagi siswa dikelas menjadi beberapa kelompok yang terdiri dari dua orang. Setiap siswa di dalam kelompok berbagi peran sebagai problem solver (penyelesai masalah) atau listener (pendengar) dengan aturan yang telah ditentukan. Teknik ini dapat meningkatkan keterampilan analitis dengan membantu siswa memformulasikan gagasan, melatih konsep, memahami sususnan langkah yang mendasari pemikiran mereka, mengidentifikasi kesalahan dalam pemecahan masalah oran lain, dan dapat mendorong terbentuknya pemahaman yang lebih dalam dan lengkap (Barkley, 2012).

Berdasarkan uraian di atas, maka perlu diadakan penelitian lebih lanjut yaitu meningkatkan kemampuan pemecahan masalah matematis siswa dengan teknik TAPPS. Oleh karena itu, penelitian ini mengenai "Upaya Meningkatkan Kemampuan Pemecahan Masalah Matematis Siswa Menggunakan Teknik Pembelajaran TAPPS pada Pokok Bahasan Kubus dan Balok di Kelas VIII-5 SMP Negeri 27 Jakarta".

\section{B. Fokus Penelitian}

Berdasarkan latar belakang yang telah diuraikan di atas, maka dikemukakan fokus dari penelitian ini adalah upaya meningkatkan kemampuan pemecahan masalah matematis siswa menggunakan teknik pembelajaran TAPPS pada pokok bahasan kubus dan balok di kelas VIII-5 SMP Negeri 27 Jakarta. Pertanyaan yang diajukan pada penelitian ini yaitu: Bagaimana penerapan teknik pembelajaran TAPPS pada pokok bahasan kubus dan balok dapat meningkatkan kemampuan pemecahan masalah matematis siswa kelas VIII-5 SMP Negeri 27 Jakarta?

\section{Tujuan Penelitian}

Tujuan penelitian ini adalah untuk meningkatkan kemampuan pemecahan masalah matematis siswa melalui penerapan teknik pembelajaran TAPPS di kelas VIII-5 SMP Negeri 27 Jakarta pada pokok bahasan kubus dan balok.

\section{Manfaat Penelitian}

Penelitian ini diharapkan dapat memberikan manfaat, antara lain:

1. Bagi siswa, khususnya siswa kelas VIII-5 SMP Negeri 27 Jakarta, dapat meningkatkan kemampuan pemecahan masalah matematis untuk mengoptimaljan hasil pembelajaran matematika.

2. Bagi guru, khususnya guru matematika SMP Negeri 27 Jakarta,diharapkan dapat menjadi pertimbangan dalam menentukan teknik pembelajaran yang diterapkan pada saat proses pembelajaran dalam upaya meningkatkan kemampuan pemecahan masalah matematis siswa.

3. Bagi sekolah, khususnya SMP Negeri 27 Jakarta, diharapkan dapat memberikan informasi untuk meningkatkan kualitas pembelajaran di sekolah khususnya dalam pemilihan teknik pembelajaran matematika.

\section{KAJIAN PUSTAKA}

A. Deskripsi Teoretis 


\section{Kemampuan Pemecahan Masalah Matematis}

Kemampuan berasal dari kata mampu yang artinya kuasa, sanggup melakukan sesuatu, dapat. Kata mampu mendapat imbuhan ke- dan -an menjadi kemampuan yang artinya kesanggupan, kecakapan, kekuatan (Indarawan, 2000). Kemampuan seseorang dalam melakukan sesuatu dapat di[peroleh dengan cara belajar bersungguh-sungguh atau berlatih, hal ini sesuai dengan yang dikatakna Munandar dalam bukunya bahwa kemampuan atau kesanggupan adalah kecakapan atau kekuatan seseorang untuk dapat berbuat atau melakukan suatu tindakan sebagai suatu hasil dari pembawaan atau latihan. (Munandar, 2005).

Suherman (dalam Husna, 2013) mengemukakan bahwa suatu masalah biasanya memuat suatu situasi yang mendorong seseorang untuk menyelesaikannya akan tetapi tidak tahu secara langsung apa yang harus dikerjakan untuk menyelesaikannya. Hal ini sesuai dengan yang dikatakan Sumarmo bahwa suatu tugas matematika digolongkan sebagai masalah apabila tidak dapat segera diperoleh cara menyelesaikannya namun harus melalui beberapa kegiatan lainnya yang relevan (Sumarmo, 2014). Hal ini berarti apabila seseorang menjawab pertanyaan dengan mengetahui langsung prosedur untuk menjawabnya maka pertanyaan tersebut tidak dapat dikatakan sebagai masalah.

Pemecahan masalah adalah proses menerapkan pengetahuan yang telah diperoleh sebelumnya ke dalam situasi baru yang belum dikenal (Wardani, 2008). Oleh karena itu untuk menyelesaikan suatu masalah siswa harus menguasai hal-hal yang dipelajari sebelumnya yaitu mengenai pengetahuan, keterampilan dan pemahaman (Hudojo, 2003). Berdasarkan beberapa pendapat di atas, maka dapat dikatakan bahwa kemampuan pemecahan masalah merupakan potensi atau kecakapan yang dimiliki seseorang untuk menggabungkan konsep-konsep, pengetahuan, pemahaman, dan keterampilan yang dimilikinya untuk menyelesaikan suatu masalah yang baru dihadapinya.

Indikator yang menunjukkan kemampuan pemecahan masalah matematis dalam penelitian ini mengikuti tahapan Polya yaitu: (1) Memahami masalah, meliputi kemampuan mengidentifikasi unsur-unsur yang diketahui, ditanyakan, dan kecukupan unsur yang diperlukan, (2) Menyusun rencana pemecahan masalah, (3) Melaksanakan rencana penyelesaikan masalah, dan (4) Melakukan pengecekan kembali terhadap hasil atau jawaban.

\section{Teknik TAPPS}

TAPPS adalah singkatan dari Thinking Aloud Pair Problem Solving. Teknik pembelajaran Thinking Aloud Pair Problem Solving (TAPPS) diperkenalkan pertama kali oleh Claparade yang kemudian digunakan oleh Bloom dan Broder untuk meneliti proses pemecahan masalah pada mahasiswa. Kemudian Art Whimbey dan Jack Lochhead telah mengembangkan teknik ini untuk pengajaran membaca, matematika, dan fisika.

Dalam bahasa Indonesia Thinking Aloud artinya berfikir secara lisan, Pair artinya berpasangan dan problem solving artinya penyelesaian masalah, sehingga dapat diartikan Thinking Aloud Pair Problem Solving (TAPPS) adalah berpikir lisan secara berpasangan untuk dapat memecahkan atau menyelesaikan suatu masalah. Untuk menerapkan teknik pembelajaran TAPPS siswa di kelas di bagi menjadi beberapa tim, setiap tim terdiri dari 2 orang siswa, salah satunya bertugas sebagai problem solver (PS) dan yang lainnya sebagai listener (L), namun jika jumlah siswa dalam kelas tersebut ganjil maka terdapat tim yang terdiri dari 3 siswa. Setiap anggota tim memiliki tugas masing-masing sesuai aturan yang sudah ditetapkan (Stice, 1987).

Peran guru di kelas dibatasi oleh aturan yang telah ditetapkan yaitu guru hanya duduk diantara pasangan siswa, memonitor aktivitas siswa dan memberikan perhatian khusus kepada listener, dalam hal ini guru dapat membantu mengarahkan listener untuk mengajukan pertanyaan kepada PS. Hal ini dilakukan karena teknik pembelajaran ini akan berhasil dicapai jika listener berhasil membuat problem solver memberikan alasan dan menjelaskan apa yang mereka lakukan untuk memecahkan masalah.

Secara sistematis, prosedur teknik pembelajaran TAPPS adalah sebagai berikut (1) Pengajar menyampaikan pokok materi pembelajaran dan bersama siswa membahas contoh soal mengenai materi, (2) Pengajar membagikan masalah yang berbeda kepada PS dan L. (3) PS dan L mempelajari masalah masing-masing selama lima menit, (4) S membaca soal lalu 
menyelesaikan permasalahan sambil menjelaskan setiap langkah penyelesaian kepada L. (5) L mendengarkan penjelasan PS sembari mengamati proses penyelesaian masalah, bertanya jika ada hal yang kurang dipahami atau memberikan saran ketika PS merasa kesulitan. (6) Pengajar berkeliling kelas mengamati dan membantu kelancaran proses. (7) Setelah soal pertama terpecahkan, PS dan L bertukar peran dan melakukan prosedur kembali seperti di atas. (Mulyanti,, 2014)

\section{Bangun ruang sisi datar}

Materi geometri yang diajarkan pada siswa kelas VIII semester genap adalah bangun ruang sisi datar. Bangun ruang sisi datar terdiri atas kubus, balok, prisma, dan limas. Sebelum mempelajari pokok bahasan ini siswa sudah terlebih dahulu mempelajari bangun datar. Standar kompetensi yang tercakup dalam materi bangun ruang sisi datar ini yaitu, memahami sifat-sifat kubus, balok, prisma, limas dan bagian-bagiannya serta menentukan ukurannya. Standar kompetensi tersebut diuraikan menjadi beberapa kompetensi dasar, yaitu, mengidentifikasi sifat-sifat kubus, balok, prisma dan limas serta bagian-bagiannya. membuat jaring-jaring kubus, balok, prisma, dan limas, dan enghitung luas permukaan dan volume kubus, balik, prisma dan limas. Pada penelitian kali ini, pokok bahasan bangun ruang sisi datar yang akan dipelajari adalah kubus dan balok.

\section{B. Penelitian yang Relevan}

Terdapat beberapa penelitian yang relevan dengan penelitian ini, antara lain yaitu penelitian yang dilakukan oleh Irawan pada tahun 2007 yang berjudul "Pembelajaran Thinking Aloud Pair Problem Solving untuk meningkatkan kemampuan berpikir kritis matematis dan motivasi belajar matematika pada siswa SMA“. Kesimpulan dari penelitian Irawan adalah pembelajaran TAPPS dapat meningkatkan kemampuan berpikir kritis matematis dan memotivasi belajar matematika siswa SMA.

Penelitian berikutnya yang relevan dengan penelitian ini adalah penelitian yang dilakukan oleh Yuniawatika yang berjudul "Penerapan Metode Thinking Aloud Pair Problem Solving (TAPPS) untuk Meningkatkan Kemampuan Komunikasi Matematik Siswa SMP”. Berdasarkan hasil penelitan, Yuniawatika menyimpulkan bahwa dengan menerapkan metode TAPPS dapat meningkatkan kemampuan komunikasi matematik siswa. Selain itu, sebagian besar siswa menunjukkan respon yang positif terhadap pembelajaran yang telah dilakukan.

Mulyanti pada tahun 2014 yang berjudul "Penerapan pembelajaran kolaboratif teknik thinking aloud pair problem solving (TAPPS) untuk meningkatkan kebiasaan berpikir dan kemampuan pemecahan masalah". Kesimpulan dari penelitian tersebut adalah kebiasaan berpikir dan kemampuan pemecahan masalah mahasiswa meningkat setelah melaksanakan proses pembelajaran kolaboratif teknik TAPPS.

Beberapa penelitian di atas dikatakan relevan dengan penelitian ini dilihat dari teknik pembelajaran yang diterapkan yaitu teknik TAPPS sebagai upaya untuk meningkatkan salah satu aspek kemampuan siswa. Hasil dari penelitian-penelitian terdahulu yang relevan dengan penelitian ini meyakinkan peneliti untuk menerapkan teknik pembelajaran TAPPS guna meningkatkan kemampuan pemecahan masalah matematis siswa.

\section{Kerangka Berpikir}

Pemecahan masalah merupakan suatu aktivitas dasar bagi manusia. Kenyataan menunjukkan bahwa sebagian besar kehidupan manusia dihadapkan dengan masalah. Oleh sebab itu, kemampuan pemecahan masalah harus dilatih sejak dini agar bisa dijadikan bekal dalam menghadapi tantangan di masa yang akan datang. Adapun tujuan pembelajaran pada hakekatnya adalah suatu proses terus-menerus manusia untuk menanggulangi masalahmasalah yang dihadapi. Pemecahan masalah dapat diajarkan melalui pembelajaran apapun, khususnya matematika karena matematika memiliki peran penting dalam proses berpikir seseorang secara analitis dan sistematis.

Berdasarkan hasil observasi dan tes penelitian terdahulu dapat disimpulkan bahwa kemampuan siswa dalam menyelesaikan soal pemecahan masalah masih rendah. Hal ini terjadi karena proses pembelajaran yang kurang melatih siswa untuk membuka pikirannya 
dalam menyelesaikan masalah, siswa tidak terbiasa mengerjakan soal-soal non-rutin dan soalsoal berbentuk cerita sehingga siswa tidak terbiasa untuk menggali ide atau gagasan dan mengaplikasikan pengetahuan mereka. Selain itu, siswa menganggap soal-soal berbentuk uraian, soal cerita maupun soal non-rutin adalah soal yang yang sulit. Sehingga mereka kurang minat untuk menyelesaikan soal tersebut. Oleh karena itu, untuk meningkatkan kemampuan pemecahan masalah sebaiknya siswa dibiasakan mengerjakan soal non rutin yang memberikan kesempatan kepada siswa untuk menggali ide atau gagasan, mengasa keterampilan, dan mengaplikasikan pengetahuan yang dimiliki.

Salah satu teknik pembelajaran yang memberikan kesempatan kepada siswa untuk menggali ide atau gagasan, mengasa keterampilan, dan mengaplikasikan pengetahuan yang dimiliki adalah Teknik Pembelajaran Thinking Aloud Pair Problem Solving (TAPPS). TAPPS adalah suatu teknik pembelajaran penyelesaian masalah yang dikerjakan secara kolaborarif, dimana siswa di dalam kelas dibagi menjadi beberapa kelompok, setiap kelompok terdiri dari 2 orang, kecuali jika jumlah siswa dalam kelas tersebut ganjil maka terdapat siswa yang terdiri dari 3 orang. Di setiap kelompok, satu orang siswa bertugas sebagai problem solver dan siswa lainnya sebagai listener. Setiap anggota memiliki tugas masing-masing yang telah ditetapkan.

Pembelajaran TAPPS melibatkan siswa dalam proses pembelajaran yang aktif, kolaboratif, berpusat pada siswa, dan memberikan tanggung jawab kepada siswa untuk menyelesaikan permasalahan yang diberikan, sehingga siswa dapat mengembangkan kemampuan berpikirnya dalam memecahkan masalah. Pembelajaran dengan teknik TAPPS juga membantu siswa meningkatkan keterampilan analitis dengan memformulasikan gagasan, melatih konsep, memahami susunan langkah yang mendasari pemikiran mereka, dan mengidentifikasi kesalahan dalam pemecahan masalah orang lain karena mengharuskan siswa untuk mengkaitkan informasi dengan kerangka-kerangka konseptual yang ada dan mengaplikasikan informasi yang diperoleh dengan situasi-situasi baru, TAPPS juga dapat mendorong terbentuknya pemahaman yang lebih lengkap dan mendalam.

Dengan menerapkan teknik pembelajaran Thinking Aloud Pair Problem Solving (TAPPS) siswa dapat terbiasa menyelesaikan pemecahan masalah matematis secara sistematis dan langkah-langkah yang jelas. Sehingga diharapkan dengan menggunakan teknik pembelajaran Thinking Aloud Pair Problem Solving (TAPPS) kemampuan pemecahan masalah matematis siswa dapat meningkat.

\section{Hipotesis Tindakan}

Berdasarkan latar belakang masalah serta penguatan dari landasan teori yang telah diuraikan di atas, maka hipotesis tindakan pada penelitian ini adalah penerapan teknik pembelajaran Thinking Aloud Pair Problem Solving (TAPPS) dapat meningkatkan kemampuan pemecahan masalah matematis siswa kelas VIII-5 SMP Negeri 27 Jakarta pada pokok bahasan kubus dan balok.

\section{METODOLOGI PENELITIAN}

\section{A. Tujuan khusus penelitian}

Penelitian ini secara khusus bertujuan untuk meningkatkan kemampuan pemecahan masalah matematis siswa menggunakan teknik pembelajaran Thinking Aloud Pair Problem Solving (TAPPS) di kelas VIII-5 SMP Negeri 27 Jakarta.

\section{B. Pendekatan dan Jenis Penelitian}

Pendekatan penelitian yang digunakan adalah pendekatan metodologi kualitatif.Jenis penelitian kualitatif yang dipilih dalam penelitian ini adalah classroom action research dalam bahasa Indonesia berarti penelitian tindakan kelas (PTK). Penelitian tindakan kelas termasuk dalam salah satu action research. Penelitian tindakan kelas dilakukan oleh guru karena guru dekat dengan masalah. Tujuan dari penelitian tindakan kelas adalah untuk memperbaiki dan meningkatkan kualitas pembelajaran di dalam kelas. Manfaat penelitian tindakan kelas adalah memperbaiki permasalahan yang ada di dalam proses pembelajaran. Prosedur pelaksanaan 
penelitian tindakan kelas terdiri dari planning (merencanakan), action (melakukan tindakan), observation (mengamati), reflection (merefleksi), dan replanning (merencanakan kembali).

\section{Kehadiran Peneliti dan Lokasi Penelitian}

Selama proses penelitian berlangsung, peneliti (participant observer) dituntut untuk hadir, hal tersebut agar pengumpulan data selama penelitian berlangsung dilakukan dalam situasi yang sesunggguhnya. Participant observer bertindak sebagai perencana dan pengamat selama kegiatan penelitian berlangsung. Selama penelitian berlangsung guru dibantu oleh participant observer dan dua orang observer. Guru berperan dalam melaksanakan rencana penelitian yang telah dibuat. Sedangkan, observer berperan dalam membantu participant observer untuk mengamati pelaksanaan tindakan sekaligus sumber data guna menguji kebsahan data.

Penelitian ini dilaksanakan di Sekolah Menengah Pertama (SMP) Negeri 27 Jakarta yang terletak di Jalan Komplek PTB Duren Sawit, Jakarta Timur. Penelitian ini dilakukan di kelas VIII-5 pada semester genap tahun pelajaran 2015/2016 .

\section{Sumber dan Jenis Data}

Sumber data pada penelitian tindakan kelas ini adalah seluruh siswa kelas VIII-5 SMP Negeri 27 Jakarta yang berjumlah 36 orang.Jenis data yang dikumpulkan dalam penelitian ini yaitu berupa data kuantitatif dan kualitatif, data kuantitatif berupa hasil tes prapenelitian dan hasil tes tiap akhir siklus dan data kualitatif berupa data hasil pengamatan setiap siklus, catatan lapangan selama pembelajaran berlangsung, dan hasil wawancara

\section{E. Subyek dan Instrumen Penelitian}

Subyek penelitian tindakan kelas ini adalah enam orang siswa kelas VIII-5 SMP Negeri 27 Jakarta yang ditentukan berdasarkan tingkat prestasi hasil belajar matematika. Enam orang siswa tersebut dipilih berdasarkan hasil prapenelitian dan berdasarkan diskusi dengan guru matematika. Siswa kelas VIII-5 dibagi ke dalam 3 kelompok yaitu kelompok atas, kelompok menengah, dan kelompok bawah. Setiap kelompok diambil 2 orang siswa, sehingga diperoleh 6 orang siswa yang akan menjadi subjek penelitian. Subyek penelitian ini diwawancarai dan dapat berubah berdasarkan pertimbangan yang disesuaikan dengan temuan selama penelitian serta hasil diskusi antara peneliti, guru, dan observer.

Instrumen penelitian dalam penelitian ini adalah :

a. Lembar pengamatan kegiatan pembelajaran

b. Lembar catatan lapangan

c. Lembar tes kemampuan pemecahan masalah matematis pada setiap akhir siklus

d. Pedoman wawancara dan alat rekam

e. Dokumentasi dan alat dokumentasi berupa kamera digital

\section{F. Desain Penelitian}

Desain penelitian dalam penelitian ini adalah prapenelitian, prasiklus, siklus I, siklus II, dan siklus III. Setiap siklus terdiri dari empat tahapan yaitu perencanaan, pelaksanaan, analisis, dan refleksi.

\section{G. Teknik Pengumpulan Data}

Data tes prapenelitian diperoleh dari hasil tes yang diberikan participant observer sebelum penelitian dimulai. Data kemampuan pemecahan masalah matematis diperoleh dari setiap siklus. Soal yang diberikan merupakan soal uraian yang berkaitan dengan materi yang telah diberikan. Data hasil pengamatan dan catatan lapangan setiap siklus yang diperoleh pada saat pembelajaran berlangsung. Data hasil wawancara diperoleh dari hasil rekaman wawancara yang bersumber dari siswa. Dokumentasi aktivitas siswa diambil pada setiap siklus dengan menggunakan handphone.

\section{H. Validitas Data}

Pengecekan keabsahan data, penelitian ini melakukan pengecekan data melalui teknik triangulasi. Definisi triangulasi menurut Iskandar yaitu "Triangulasi merupakan teknik pemeriksaan keabsahan data yang memanfaatkan sesuatu yang lain di luar data itu untuk keperluan pengecekan atau sebagai pembanding terhadap suatu data”. 
Teknik triangulasi yang dipilih dalam penelitian ini adalah triangulasi sumber dan teknik. Teknik triangulasi sumber merupakan pengecekan keabsahan data melalui informasi yang diberikan oleh sumber yang berbeda-beda yaitu guru, siswa, dan observer. Sedangkan triangulasi teknik adalah pengecekan keabsahan data dari sumber yang sama menggunakan teknik yang berbeda. Dalam penelitian ini data yang akan dibandingkan adalah data hasil pengamatan, data hasil wawancara dan dokumen.

\section{Analisis Data}

Proses analisis data terdiri atas analisis data pada saat penelitian di lapangan dan analisis data yang sudah terkumpul. Analisis data ini diawali dengan mengumpulkan seluruh data yang ada dari berbagai sumber, baik berupa data kuantitatif maupun data kualitatif. Selanjutnya menyusun data, mengelompokkan data dan mengkategorikannya. Pengategorian data disusun berdasarkan kegiatan pada tahap-tahap pembelajaran. Data kualitatif yang terkumpul berupa kalimat-kalimat dan data-data tentang aktivitas-aktivitas guru dan siswa, akan dianalisis dan diubah menjadi kalimat-kalimat bermakna dan ilmiah.

Data kuantitatif yang dianalisis yaitu tes awal dan tes akhir siklus. Data tersebut akan dianalisis secara kuantitatif. Dalam setiap tes, penilaian dilakukan sesuai dengan pedoman penskoran tes kemampuan pemecahan masalah matematis.

\section{J. Tahap-tahap Penelitian}

Penelitian dimulai dengan melakukan kegiatan prapenelitian bulan November 2015. Kegiatan prasiklus pada tanggal 2 Maret 2016, kemudian dilanjutkan dengan kegiatan siklus I pada tanggal 16, 21, 23 dan 24 Maret 2016, siklus II pada tanggal 4, 6, dan 7 April 2016, dan siklus III pada tanggal 11, 13, dan 14 April 2016.

\section{K. Ketercapaian Siklus}

Indikator ketercapaian siklus yang digunakan untuk mengetahui hasil yang akan dicapai dalam penelitian ini adalah

1. Meningkatnya kemampuan pemecahan masalah matematis siswa yang dilihat dari nilai rata-rata siswa dalam menyelesaikan tes pemecahan masalah matematis siswa pada setiap akhir siklus, minimal mencapai nilai kategori baik yaitu 71-85.

2. Siswa mencapai tuntas belajar yaitu mencapai nilai 75 pada tes akhir siklus, minimal $80 \%$ dari jumlah seluruh siswa yang mengikuti tes pada akhir siklus.

\section{PAPARAN DATA, HASIL PENELITIAN, DAN PEMBAHASAN}

Berdasarkan penelitian yang telah dilakukan selama kurang lebih dua bulan mendapatkan hasil sebagai berikut

Penerapan teknik pembelajaran TAPPS dapat meningkatkan kemampuan pemecahan masalah matematis siswa kelas VIII-5 SMP Negeri 27 Jakarta pada pokok bahasan kubus dan balok.

Pemecahan masalah merupakan salah satu tujuan dari kurikulum matematika yang sangat penting dimiliki oleh siswa untuk mengasah kemampuan berpikirnya. Kemampuan pemecahan masalah membatu siswa untuk berpikir secara sistematis, analitis, dan mengaitkan pengetahuan-pengetahuan yang dimiliki sebelumnya untuk menyelesaikan masalah baru. Kemampuan tersebut sangat berguna sebagai bekal dalam memecahkan permasalahan di dalam kehidupan sehari-hari.

Penerapan teknik pembelajaran Thinking Aloud Pair Problem Solving (TAPPS) dalam pembelajaran matematika memiliki kelebihan dibandingkan dengan teknik pembelajaran yang digunakan guru sebelumnya. Pembelajaran dengan teknik TAPPS membantu siswa mendiagnosa kesalahan-kesalahn dalam logikanya, meningkatkan keterampilan analitis dengan memformulasikan gagasan, melatih konsep, memahami susunan langkah, dan mengidentifikasi kesalahan dalam penalaran orang lain, hal ini terjadi karena teknik TAPPS mengharuskan siswa untuk mengaitkan informasi dengan kerangka-kerangka konseptual yang ada dan mengaplikasikan informasi yang diperoleh dengan situasi yang baru sehingga teknik TAPPS juga dapat mendorong terbentuknya pemahaman yang lebih mendalan dan lebih lengkap. 
Berdasarkan hasil pengamatan, penerapan teknik pembelajaran TAPPS membuat suasana belajar menjadi lebih aktif dan siswa terlihat lebih antusias Teknik pembelajaran ini membiasakan siswa untuk menyelesaikan soal pemecahan masalah dan menjelaskannya kepada teman kelompoknya. Berdasarkan hasil wawancara dengan keenam subjek penelitian, siswa lebih antusias dalam belajar dengan teknik TAPPS karena waktu kegiatan pembelajaran terasa lebih cepat dan soal yang diberikan sangat menantang membuat siswa penasaran untuk menyelesaikannya. Siswa menjadi teliti saat mengerjakan soal dan terbiasa mengerjakan soal yang sulit serta merasa mudah mengerjakan soal-soal latihan yang ada di buku paket, siswa menjadi lebih mandiri dan tidak merasa ngantuk saat kegiatan pembelajaran, selain itu siswa jadi lebih bisa mengungkapkan pendapatnya dan menjelaskannya kepada teman.

Selama proses pembelajaran dengan teknik TAPPS di kelas VIII-5 menunjukkan adanya peningkatan pada kemampuan pemecahan masalah matematis siswa pada tiap siklusnya, baik dilihat secara keseluruhan siswa kelas VIII-5 maupun keenam subjek penelitian. Tahapan pertama yang menunjang meningkatnya kemampuan pemecahan masalah matematis siswa adalah tahap eksplorasi dimana siswa diminta mengerjakan LKS secara berdiskusi. LKS yang diberikan disusun untuk membantu siswa belajar secara mandiri sebelum materi dijelaskan oleh guru, siswa diharapkan dapat menemukan rumus unsur-unsur, luas permukaan, maupun volume kubus dan balok dengan menggunakan LKS yang diberikan. Guru membahas LKS yang telah dikerjakan oleh siswa dengan metode tanya jawab, dan memberikan contoh soal yang berkaitan dengan LKS. Melalui aktivitas eksplorasi siswa membangun pemahaman konsep untuk dapat menyelesaikan soal pemecahan masalah yang akan diberikan.

Tahapan kedua adalah elaborasi. Siswa dituntut untuk berperan aktif pada tahap ini, karena siswa harus mengerjakan 2 soal dengan berbagi peran sebagai problem solver dan listener. Secara keseluruhan penerapan teknik TAPPS dslam penelitian ini memiliki kekurangan di alokasi waktu saat tahap elaborasi. Pada siklus I siswa merasa kesulitan terhadap soal yang diberikan, sehingga siswa membutuhkan waktu yang lama untuk mengerjakannya. Salah satu unsur yang paling penting dalam menerapkan pembelajaran dengan teknik TAPPS yaitu merancang sebuah tugas pembelajaran yang sesuai, apabila tugas pembelajaran tidak sesuai atau tidak dipahami dengan jelas oleh siswa maka kegiatan pembelajaran menjadi lambat, perhatian tidak terfokus, dan sikap frustasi akan muncul Oleh karena itu dilakukan perbaikan-perbaikan untuk pertemuan berikutnya. Perbaikan yang dilakukan pada tahap ini terkait soal yang diberikan, waktu, dan peran guru. Seiring dengan perbaikan yang diberikan terjadi pula peningkatan kemampuan pemecahan masalah matematis siswa kelas VIII-5. Hal ini sesuai dengan yang dikatakan oleh Barkley bahawa teknik pembelajaran TAPPS menawarkan prosedur-prosedur untuk melatih siswa dalam meningkatkan keterampilan penyelesaian masalah.

Berdasarkan data hasil penelitian yang telah dipaparkan, dapat dikatakan bahwa kemampuan pemecahan masalah matematis siswa kelas VIII-5 SMPN 27 Jakarta mengalami peningkatan, baik secara keseluruhan siswa kelas VIII-5 maupun keenam subjek penelitian. Nilai rata-rata kemampuan pemecahan masalah matematis siswa kelas VIII-5 pada siklus III sudah melebihi target indikator keberhasilan yang telah ditetapkan, yaitu mencapai 87,27 dan jumlah siswa yang mencapai nilai KKM telah mencapai 86,11\%. Jadi, dapat dikatakan bahwa pembelajaran matematika dengan teknik Thinking Aloud Pair Problem Solving (TAPPS) sebagai upaya meningkatkan kemampuan pemecahan masalah matematis siswa mengalami keberhasilan dalam penerapannya pada penelitian ini.

\section{KESIMPULAN, IMPLIKASI, DAN SARAN}

A. Kesimpulan

Berdasarkan hasil pelaksanaan penelitian tindakan kelas mengenai penerapan teknik Thinking Aloud Pair Problem Solving (TAPPS) dalam pembelajaran matematika diperoleh kesimpulan bahwa penerapan teknik TAPPS dapat meningkatkan kemampuan pemecahan masalah matematis siswa kelas VIII-5 SMP Negeri 27 Jakarta pada pokok bahasan kubus dan balok. Pembelajuaran dengan teknik TAPPS melatih siswa untuk memahami sususnan langkah dalam penyelesaian masalah, meningkatkan keterampilan, mengaitkan informasi dengan kerangka konseptual yang telah diketahui sehingga dapat meningkatkan kemampuan pemecahan masalah. Hal ini didukung dengan meningkatnya nilai rata-rata pada tes akhir yang diberikan setiap siklus. Rata-rata nilai tes akhir kemampuan pemecahan masalah 
matematis siswa kelas VIII-5 pada penelitian pendahuluan adalah 39,97 berada pada kategori sangat kurang. Siklus I meningkat menjadi 67,71 berada pada kategori cukup, pada siklus II meningkat menjadi 79,98 berada pada kategori baik, dan pada siklus III meningkat menjadi 87,27 berada pada kategori sangat baik. Jumlah siswa yang mencapai nilai kriteria ketuntasan minimal (KKM) yaitu 75 juga mengalami peningkatan. Pada penelitian pendahuluan hanya satu siswa, meningkat pada siklus I menjadi 13 siswa atau 36,11\% dari keseluruhan siswa, pada siklus II menjadi 25 orang atau 69,44\%, dan meningkat menjadi 31 orang atau $86,11 \%$ dari keseluruhan siswa pada siklus III.

B. Implikasi

Berdasarkan kesimpulan yang telah disebutkan di atas, implikasi yang terjadi dalam penelitian ini adalah kemampuan pemecahan masalah matematis siswa kelas VIII-5 SMP Negeri 27 Jakarta pada pokok bahasan kubus dan balok meningkat akibat penerapan teknik pembelajaran thinking aloud pair problem solving (TAPPS) dalam pembelajaran matematika yang membiasakan siswa untuk memformulasikan gagasan, melatih konsep, memahami susunan langkah yang mendasari pemikiran siswa untuk menyelesaikan masalah, dan mengidentifikasi kesalahan dalam penalaran temannya.

\section{Saran}

Berdasarkan hasil penelitian dan kesimpulan di atas, maka saran-saran berikut ini diharapkan dapat bermanfaat dan menjadi pertimbangan bagi penelitian selanjutnya, antara lain:

1. Penentuan kelompok sebaiknya dipikirkan secara matang dengan mempertimbangkan kemampuan akademik, karakter siswa, dan disetujui oleh siswa agar diskusi dapat berjalan optimal.

2. Soal-soal pemecahan masalah yang diberikan kepada siswa harus menarik, bervariatif, dan mudah dipahami oleh siswa serta disesuaikan tingkat kesulitan dan waktu yang diberikan.

3. Guru harus disiplin terhadap waktu yang telah ditetapkan untuk setiap aktivitas siswa agar estimasi waktu sesuai dengan perencanaan.

4. Penerapan teknik thinking aloud pair problem solving (TAPPS) dalam pembelajaran matematika dapat dijadikan alternatif teknik pembelajaran tetapi harus dengan perencanaan yang matang agar tujuan pembelajaran dapat tersampaikan dengan baik.

5. Siswa perlu dibiasakan menerapkan tahapan Polya untuk mempermudah menyelesaikan soal yang diberikan.

6. Guru perlu memotivasi siswa agar memanfaatkan waktu yang diberikan dengan baik.

\section{DAFTAR PUSTAKA}

Barkley, Elizabeth. 2012. Collaborative Learning Techniques. Bandung: Nusa Media.

Blitzer, Robert. 2011. Thinking Mathematically. USA: Prentice Hall.

Hudojo, Herman. 2003. Pengembangan Kurikulum dan Pembelajaran Matematika. Malang: Universitas Negeri Malang.

Husna. 2013. "Peningkatan Kemampuan Pemecahan Masalah dan Komunikasi Matematis Siswa Sekolah Menengah Pertama melalui Model Pembelajaran Kooperatif Tipe Think Pair Share (TPS)". Jurnal. ISSN: 2302-5158

Irawan. 2007. "Pembelajaran Thinking Aloud Pair Problem Solving (TAPPS) Untuk Meningkatkan Kemampuan Berpikir Kritis Matematis dan Motivasi Belajar Matematika Siswa SMA”. Tesis. Bandung: Universitas Pendidikan Indonesia.

Iskandar. 2012. Penelitian Tindakan Kelas. Jakarta: Referensi.

Moleong, Lexy J. 2000. Metodologi Penelitian Kualitatif. Bandung: Remaja Rosdiakarya. 
Mulyanti, Khairaningrum. "Penerapan Pembelajaran Kolaboratif Teknik Thinking Aloud Pair Problem Solving (TAPPS) Untuk Meningkatkan Kebiasaan Berpikir dan Kemampuan Pemecahan Masalah”. Tesis. Bandung: Universitas Pendidikan Indonesia.

Munandar, Utami S. 2005. Mengembangkan Bakat dan Kreatifitas Anak Sekolah. Jakarta: PT Gramedia Widiasarana.

Shadiq, Fajar. 2004. Pemecahan Masalah, Penalaran dan Komunikasi, Yogyakarta: Depdiknas Direktorat Jendral Pendidikan Dasar dan Menengah Pusat Pengembangan Penataran Guru (PPG) Matematika.

Soemarmo, Utari. 2014. Penilaian Pembelajaran Matematika. Bandung: PT Refika Aditama.

Stice, James E. 1987. Teaching Problem Solving. The University of Texas at Austin.

Wardhani, Sri. 2008. Analisis SI dan SKL Mata Pelajaran Matematika SMP/MTs untuk Optimalisasi Pencapaian Tujuan. Yogyakarta: Pusat Pengembangan dan Pemberdayaan Pendidik dan Tenaga Kependidikan Matematika.

WS, Indrawan. 2000. Kamus Lengkap Bahasa Indonesia. Jombang: Lintas Media.

Yuniawatika, 2013. "Penerapan Metode Thinking Aloud Pair Problem Solving (TAPPS) Untuk Meningkatkan Kemampuan Berpikir Kritis Matematis dan Motivasi Belajar Matematika Siswa SMA”. Jurnal. STKIP Siliwangi. 